\title{
Pengaruh Kepemimpinan dan Value for Money terhadap Good Government Governance Pada Badan Perencanaan Pembangunan Daerah (BAPPEDA) Kota Bandung
}

\author{
Indra Firmansyah ${ }^{1}$, Prima Destiani Rahmawati ${ }^{2}$ \\ Prodi D4 Akuntansi Politeknik Pos Indonesia ${ }^{1}$ \\ Email : indrafirmansyah@poltekpos,ac.id \\ Prodi D4 Akuntansi Politeknik Pos Indonesia ${ }^{2}$ \\ Email : primadestiani@gmail.com
}

\begin{abstract}
Abstrak
Kepemimpinan merupakan suatu faktor utama untuk mencapai tujuan dalam organisasi yang dipimpinnya. Sedangkan value for money merupakan konsep pengelolaan organisasi sektor publik yang mendasarkan pada tiga elemen utama, yaitu ekonomis, efisiensi, dan efektivitas. Penerapan karakteristik good government governance pada dasarnya merupakan perwujudan keamanahan pengelola dalam menjalankan tugas yang diamanatkan kepadanya dan kejujuran dalam pelaporan keuangan. karakteristik good government governance yaitu partisipasi, aturan hukum, transparan, respon, orientasi konsensus, keadilan, efektif dan efisiensi, akuntabilitas, dan visi strategi.

Tujuan dari penelitian ini yaitu untuk mengetahui pengaruh kepemimpinan dan value for money terhadap Good Government Governance secara parsial dan hubungan dengan tiap variable yang terkait.

Berdasarkan hasil perhitungan koefisien jalur diketahui bahwa kepemimpinan memiliki koefisien jalur sebesar 0,616 dan value for money memiliki koefisien jalur sebesar 0,186, korelasi berganda diperoleh sebesar 0,705 yang dikategorikan kuat karena berada diantara 0,60-0,799. Hasil koefisien determinasi diperoleh sebesar 57,5\%. Sedangkan hasil uji f dapat dilihat $f_{\text {hitung }}$ sebesar 43,271 dan $f_{\text {tabel }}$

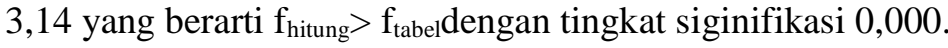

Dari kesimpulan diatas dapat dikatakan bahwa variabel kepemimpinan dan value for money secara simultan berpengaruh positif signifikan terhadap good government governance di Badan Perencanaan Pembangunan Daerah (BAPPEDA) Kota Bandung.
\end{abstract}

Kata Kunci : Kepemimpinan, Value for Money, Good Government Governance

\begin{abstract}
Leadership is a major factor to achieve the objectives of the organization he leads. While the value for money is the concept of the management of public sector organizations based on three main elements, economy, efficiency and effectiveness. In achieving good governance, clean and dignified, professional and responsible embodied by the figure and the bureaucracy more efficient and effective and can provide excellent service to the entire community. Application of the characteristics of good government governance is essentially a manifestation manager in performing the tasks mandated to him and honesty in financial reporting. characteristics of good government governance: participation, rule of law, transparency, response, consensus orientation, equity, effective and efficiency, accountability and strategic vision.

The purpose of this study is to determine the effect of leadership and Value for money on Good Government Governance partially and the relationship with each related variable.

Based on the results of the calculation of the path coefficient is known that the leadership has the path coefficient of 0.616 and the value for money had a path coefficient of 0.186 , obtained multiple correlation of 0.705 is considered strong because in between 0.60 to 0.799. Results obtained determination coefficient of 57.5\%. While the test results can be seen $F$ arithmetic 43.271 and $F$ table 3.14, which means $F$ arithmatic $>$ f table with siginificance 0,000 level.

From the above conclusion it can be said that the leadership variable and value for money simultaneously significant positive effect on good government governance in Regional Development Planning Board (BAPPEDA) in Bandung.
\end{abstract}

Keywords: Leadership, Value for Money, Good Government Governance 


\section{PENDAHULUAN}

Seiring berkembangnya era globalisasi maupun reformasi, terdapat tuntutan untuk meningkatkan kinerja organisasi sektor publik agar lebih berorientasi pada terwujudnya kepemimimpinan yang baik. Kepemimpinan disektor publik berpengaruh besar atas kemajuan Indonesia. Kepemimpinan yang professional dapat dilihat dari kinerja yang dilakukan karyawan/bawahan dalam menjalankan perintah atasan yang sesuai dengan tujuan organisasi.

Kepemimpinan yang baik dipengaruhi oleh tata kelola pemerintahan yang baik (good government governance). Terciptanya tata kelola pemerintahan yang baik, bersih, dan berwibawa, profesional dan bertanggungjawab yang diwujudkan dengan sosok dan perilaku birokrasi yang efisien dan efektif serta dapat memberikan pelayanan yang prima kepada seluruh masyarakat.

Pemerintah telah mengeluarkan peraturan perundang-undangan untuk mewujudkan good government goverance yaitu Undang-Undang Nomor 28 Tahun 1999 tentang Penyelenggaraan Negara yang Bersih dan Bebas Korupsi, Kolusi dan Nepotisme pasal 1 point 2 menyatakan bahwa

"penyelenggara negara yang bersih adalah penyelenggara negara yang menaati asas-asas umum penyelenggaraan negara dan bebas dari praktek korupsi, kolusi, dan nepotisme, serta perbuatan tercela lainnya" dan pasal 5 point 6 menyatakan bahwa "melaksanakan tugas dengan penuh rasa tanggungjawab dan tidak melakukan perbuatan tercela, tanpa pamrih baik untuk kepentingan pribadi, keluarga, kroni, maupun kelompok, dan tidak mengharapkan imbalan dalam bentuk apapun yang bertentangan dengan ketentuan peraturan perundang-undangan yang berlaku”.

Good government governance diterapkan untuk berusaha menjaga keseimbangan diantara pencapaian tujuan pemerintahan dan tujuan masyarakat. Tantangan dalam good government governance mencari cara untuk memaksimalkan penciptaan kesejahteraan masyarakat sedemikian rupa sehingga tidak membebankan semua biaya yang patut kepada masyarakat luas, dengan demikian perlu adanya penerapan prinsip-prinsip good government governance.

Bedasarkan peneliti terdahulu yang dilakukan oleh Endang Kuswoyo 2014 Analisis Value for Money dalam Meningkatkan Mutu Pelayanan Publik pada Koni Provinsi Bengkulu (Studi Kasus pada Program Upaya Pembinaan Atlet) memberikan gambaran perlunya value for money untuk menganalisa kinerja keuangan pemerintah sebagai dasar dan alat ukurnya.

BAPPEDA sebagai lembaga teknis yang mempunyai tugas pokok dan fungsi dalam perumusan perencanaan pembangunan daerah memiliki peran dan fungsi strategis dalam perencanaan, pelaksanaan dan pengendalian pembangunan. Untuk mendukung pelaksanaan tupoksi BAPPEDA diperlukan suatu dokumen rencana strategis yang memberikan arah kebijakan dan fokus program dalam lima tahun mendatang. Dokumen Renstra BAPPEDA tersebut harus terintegrasi dengan dokumen perencanaan pembangunan jangka menengah kota yaitu RPJMD Kota Bandung 2014-2018.

Kepemimpinan dengan konsep value for money merupakan unsur manajemen pemerintah yang penting dalam rangka mewujudkan pemerintahan yang bersih (clean government) dan tatakelola yang baik (good governance) yang pada akhirnya dapat mendorong terwujudnya tata kelola pemerintahan yang baik (good government governance). Perlunya reformasi di sektor publik untuk mewujudkan good public dan corporate governance dalam rangkaian menciptakan kesejahteraan masyarakat, maka diperlukan serangkaian reformasi di sektor publik. Hal ini juga bisa diperkuat dengan hasil penelitian sebelumnya yang dilakukan oleh Rosalinda Cahya Hutahuruk. 2009. Pengaruh Kepemimpinan terhadap Kinerja Pegawai dijelaskan disana bahwa factor kepemimpinan sangat berpengaruh tewrhadap penilaian,kinerja pegawainya

Berdasarkan fenomena dan study empiris yang dilakukan penelitian terdahulu makja penulis tertarik untukj mengambil judul "Pengaruh Kepemimpinan dan Value for Money terhadap Good Government Governance Pada Badan Perencanaan Pembangunan Daerah (BAPPEDA) Kota Bandung.

\section{B.Tujuan Penelitian}

Tujuan dari penelitian ini yaitu untuk mengetahui pengaruh kepemimpinan dan Value for money terhadap Good Government Governance secara parsial dan hubungan dengan tiap variable yang tewrkait hjuga sebagai acuan untuk penelitian selanjutnya. 


\section{TINJAUAN PUSTAKA}

\section{A. Kepemimpinan}

Kepemimpinan adalah proses untuk mempengaruhi orang lain baik di dalam organisasi maupun diluar organisasi untuk mencapai tujuan yang diinginkan dalam suatu situasi dan kondisi tertentu. Proses memengaruhi tersebut sering melibatkan berbagai kekuasaan seperti ancaman, penghargaan, otoritas maupun bujukan.

"Transisi dalam teori kepemimpinan berkembang dari waktu ke waktu berdasarkan keingintahuan para ilmuwan dan peneliti. Mula-mula kepemimpinan itu dilihat dari sudut pandang sifat, ciri atau bakat yang dibawa sejak lahir. Ketidakpuasan akan hasil dari pendekatan ciri tersebut melahirkan pendekatan kepemimpinan berdasarkan perilaku. Kedua pendekatan tersebut belum memuaskan para peneliti sehingga menggunakan pendekatan lain, yaitu keberhasilan seseorang tergantung pada situasinya. Bahkan perkembangan terakhir pendekatan kembali ke ciri-ciri seorang pemimpin" (Rivai dalam Mulyadi, 2016:23).

\section{Tugas Kepemimpinan}

Tugas kepemimpinan pada dasarnya meliputi dua bidang utama, yaitu pencapaian tujuan birokrasi dan kekompakan orang yang dipimpinnya. Menurut Keating yang dalam buku Harbani Pasolong (2015:5) mengatakan bahwa "tugas kepemimpinan yang berhubungan dengan kelompok yaitu:

1. Memulai (initiating) yaitu usaha agar kelompok mulai kegiatan atau gerakan tertentu,

2. Mengatur (regulating) yaitu tindakan untuk mengatur arah dan langkah kegiatan kelompok,

3. Memberitahu (informating) yaitu kegiatan memberi informasi, data, fakta, pendapat para anggota dan meminta dari mereka informasi, data, fakta, pendapat yang diperlukan,

4. Mendukung (supporting) yaitu usaha untuk menerima gagasan, pendapat, usul dari bawah dan menyempurnakannya dengan menambah atau mengurangi untuk digunakan dalam rangka penyelesaian tugas bersama, dan

5. Menilai (evaluating) yaitu tinfakan untuk menguji gagasan yang muncul, menyingkat lalu menyimpulkannya sebagai landasan untuk memikirkan lebih lanjut".

\section{Fungsi Kepemimpinan}

Stoner dalam Pasolong (2010:22) menyatakan bahwa "fungsi kepemimpinan adalah seorang beroperasi secara efektif kelompok memperlikan seseorang untuk melakukan dua hal fungsi yaitu berhubungan dengan tugas atau memecahkan masalah dan memelihara kelompok atau sosial, yaitu tindakan seperti menyelesaikan perselisihan dan memastikan bahwa individu merasa dihargai oleh kelompok".

Fungsi kepemimpinan menurut Siagan (2010:48-70) yaitu :

1. "Pimpinan sebagai penentu arah,

2. Pimpinan sebagai wakil dan juru bicara birokrasi,

3. Pimpinan sebagai komunikator yang efektif,

4. Pimpinan sebagai mediator, dan

5. Pimpinan selaku integrator."

\section{B. Value for Money}

Menurut Abdul Halim (2012:132) "konsep value for money merupakan konsep untuk mengukur ekonomi, efektivitas, dan efisiensi kinerja program, kegiatan dan organisasi. Konsep value for money adalah konsep yang penting dalam organisasi sektor publik sehingga seringkali disebut dengan inti dari pengukuran kinerja sektor publik. value for money juga mengandung arti sebagai penghargaan terhadap nilai uang."

\section{Pengukuran Value For Money}

Menurut Mardiasmo (2018:130) bahwa "kriteria pokok yang mendasari pelaksanaan manajemen publik dewasa ini adalah ekonomi, efisiensi, efektivitas, transparansi dan akuntabilitas publik. Agar dalam menilai kinerja organisasi dapat dilakukan secara objektif, maka diperlukan 
indikator kinerja. Indikator kinerja yang ideal harus terkait pada efisiensi biaya dan kualitas pelayanan. Sementara itu, kualitas terkait dengan kesesuaian dengan maksud dan tujuan, konsistensi, dan kepuasan publik. Kepuasan masyarakat dalam konteks tersebut dapat dikaitkan dengan semakin rendahnya complaint dari masyarakat."

Adapun langkah-langkah pengukuran value for money menurut Mardiasmo (2018:133), yaitu :

1. Pengukuran Ekonomi

Pengukuran ekonomi mempertimbangkan masukan yang dipergunakan. Ekonomi merupakan ukuran relatif.

2. Pengukuran Efisiensi

Efisiensi merupakan hal penting dari ketiga pokok bahasan value for money. Efisiensi diukur dengan rasio antara output dengan input. Semakin besar output dibanding input, maka semakiin tinggi efisiensi suatu organisasi.

$$
\text { Efisiensi }=\frac{\text { Output }}{\text { Input }}
$$

3. Pengukuran Efektivitas

Efektivitas adalah ukuran berhasil tidaknya suatu organisasi mencapai tujuannya. Apabila suatu organisasi berhasil mencapai tujuan, maka organisasi tersebut dikatakan relah berjalan dengan efektif. Hal terpenting yang perlu dicatat adalah efektivitas tidak menyatakan tentang berapa besar biaya yang telah dikeluarkan untuk mencapai tujuan tersebut.

4. Pengukuran Outcome

Outcome adalah dampak suatu program atau kegiatan terhadap masyarakat. outcome lebih tinggi nilainya dari output, karena hanya mengukur hasil tanpa mengukur dampaknya terhadap masyarakat, sedangkan outcome mengukur kualitas output dan dampak yang dihasilkan.

\section{Good Government Governance}

\section{Teori Good Government Governance}

Pemerintahan atau "government" yang berarti pengarahan dan administrasi yang berwenang atas kegiatan orang-orang dalam sebuah negara, negara bagian, kota, dan sebagainya. Atau lembaga atau badan yang menyelenggarakan pemerintahan negara, negara bagian, atau kota dan sebagainya. Sedangkan dalam kepemerintahan atau "governance" yaitu the act, fact, manner of governing. Atau dalam bahasa Indonesia yaitu tindakan, fakta, pola, dan kegiatan penyelenggaraan pemerintah. Dengan demikian governance adalah suatu kegitan (proses), sebagaimana dikemukakan oleh Koiman (1993:87) bahwa "governance merupakan serangkaian proses iteraksi sosial antara pemerintahan dengan masyarakat dalam berbagai bidang yang berkaitan dengan kepentingan masyarakat dan intervensi pemerintah atas kepentingan-kepentingan tersebut." Sedangkan menurut Sedarmayanti (2012:2) "istilah Governance tidak hanya berarti kepemerintahan sebagai suatu kegiatan tetapi juga mengandung arti pengurusan, pengelolaan, pembinaan penyelenggaraan dan juga bisa diartikan pemerintahan."

Governance sebagai proses pengambilan keputusan dan proses yang mana keputusan itu diimplementasikan, maka analisis governance difokuskan pada faktor-faktor formal dan informal yang terlibat dalam pengambilan keputusan dan implementasinya serta struktur formal dan informal yang di susun untuk mendatangkan implementasi keputusan. Governance dapat digunakan dalam beberapa konteks seperti corporate governance, international governance, national governance dan local governance.

\section{Unsur-unsur Good Government Governance}

Menurut Sedarmaryanti (2012:4) pada dasarnya unsur-unsur dalam kepemerintahan dapat dikelompokan menjadi 3 kategori, yaitu :

1. Negara/pemerintahan: konsepsi kepemerintahan pada dasarnya adalah kegiatan kenegaraan, tetapi lebih jauh dari itu melibatkan pula sektor swasta dan kelembagaan masyarakat madani.

2. Sektor swasta: pelaku sektor swasta mencakup perusahaan swasta yang aktif dalam interaksi dalam sistem pasar. 
3. Masyarakat madani: kelompok masyarakat dalam konteks kenegaraan pada dasarnya berada diantara atau tengah-tengah antara pemerintah dan perseorangan, yang mencakup baik perseorangan maupun kelompok masyarakat yang berinteraksi secara sosial, politik, dan ekonomi.

\section{Manfaat Good Government Governance}

Menurut Sedarmayanti (2012:5) manfaat good government governance dalam disebutkan :

1) Dengan terselenggaranya good governance adalah sebagai persyaratan mewujudkan aspirasi masyarakat dalam mencapai tujuan dan cita- cita bangsa dan negara.

2) Terciptanya pemerintahan yang solid dan bertanggung jawab serta efisien dan efektif.

Berdasarkan penjelasan diatas, maka dapat disimpulkan bahwa good government governance yaitu proses tata kelola pemerintahan yang demokratis, profesional menjunjung tinggi supremasi hukum dan hak asasi manusia desentralistik, partisipatif, transparan, keadilan, bersih dan akuntabel, selain berdaya guna, berhasil guna dan berorientasi pada peningkatan daya saing bangsa untuk menjadikan pemerintahan yang baik.

\section{METODOLOGI PENELITIAN \\ Metode yang Digunakan}

Penelitian deskriptif adalah penelitian yang bertujuan untuk memperoleh deskripsi tentang ciri-ciri kepemimpinan, value for money dan good government governance. Sifat penelitian verifikatif adalah untuk menguji kebenaran suatu hipotesis yang dilaksanakan melalui pengumpulan data di lapangan, dimana dalam penelitian ini akan menguji pengaruh kepemimpinan dan value for money terhadap good government governance di Badan Perencanaan Pembangunan Daerah (BAPPEDA) Kota Bandung. Jenis penelitian ini adalah jenis penelitian kuantitatif.

Mengingat penelitian ini adalah deskriptif dan verifikatif, maka metode penelitian yang digunakan adalah descriptive survey dan metode explanatory survey. Descriptive survey adalah metode penelitian yang dilakukan untuk memperoleh gambaran tentang kepemimpinan, value for money dan good government governance. Metode explanatory survey adalah metode penelitian yang dilakukan melalui penyebaran kuisioner kepada pegawai BAPPEDA Kota Bandung.

\section{Metode Pengambilan Sampel}

Teknik sampling yang digunakan proporsional stratified random sampling, yaitu teknik ini digunakan untuk mengambil sampel dengan memperhatikan starata (tingkatan) di dalam populasi. Dalam teknik ini data sebelumnya dikelompokkan dalam tingkatan-tingkatan tertentu. Masing-masing sub diusahakan homogen. Dari masing-masing sub selanjutnya diambil sebagaian anggota secara acak dengan komposisi prorsional/disproporsional.

\section{Populasi Penelitian}

Unit analisis dalam penelitian ini adalah pegawai BAPPEDA Kota Bandung yang terdiri dari golongan II, golongan III, dan golongan IV yang dikelompokan dalam 2 jenis kategori yakni laki-laki dan perempuan komposisi pegawai BAPPEDA Kota Bandung per tahun 2015 disajikan dalam Tabel 3.2 sebagai berikut :

Tabel 1. Jumlah Pegawai BAPPEDA Kota Bandung

\begin{tabular}{|c|c|c|c|c|c|}
\hline \multirow{2}{*}{ No } & \multirow{2}{*}{ Golongan } & \multicolumn{2}{|c|}{ Jumlah Pegawai } & \multirow{2}{*}{ Total } & \multirow{2}{*}{ Presentase (\%) } \\
\cline { 3 - 5 } & & Laki- laki & Perempuan & & $6 \%$ \\
\hline 1. & II & 5 & - & 5 & $79 \%$ \\
\hline 2. & III & 44 & 26 & 70 & $15 \%$ \\
\hline 3. & IV & 11 & 3 & 14 & $100 \%$ \\
\hline \multicolumn{2}{r}{ Jumlah } & 60 & 29 & 89 & \\
\hline
\end{tabular}

Sumber : BAPPEDA Kota Bandung (2015)

Populasi adalah kumpulan dari unit sampling yang meliputi satu atau lebih unit unsur (Sekaran, 2013:10). Dari Tabel 3.2 di atas, maka jumlah populasi dalam penelitian ini sebanyak 89 orang pegawai. 


\section{Sampel Penelitian}

Sampel yang menjadi sasaran penelitian adalah unsur-unsur yang berada dalam populasi. Teknik sampling yang dipilih adalah proporsional stratified random sampling methode. Teknik sampling ini digunakan untuk pengambilan sample dari anggota populasi secara acak dan berstrata secara proporsional. Sampling ini dilakukan apabila populasi heterogen (tidak sejenis). Teknik ini dilakukan dengan membuat cara lapisan-lapisan (strata), kemudian dari setiap lapisan diambil sejumlah subjek secara acak. Jumlah subjek dari setiap lapisan (strata) adalah sampel. (Sugiono, 2015:120). Sebelum pemilihan sampel dilakukan di lapangan maka terlebih dahulu peneliti menentukan kerangka sampel (sampel frame), maka dengan pertimbangan; pertama, variabel yang akan diteliti keadaannya relatif homogen, dan kedua, karena setiap satuan sampel dalam populasi mempunyai kesempatan yang sama (Harun Al-Rasyid, 2005) alasan ketiga karena adanya kendala atau keterbatasan sumber daya anatara lain waktu dan biaya, keempat karena pengambilan anggota sampel dari populasi dilakukan secara acak tanpa memperhatikan strata yang ada dalam populasi (Sugiyono, 2015). Dalam pengumpulan data dilakukan melalui kuisioner yang disebarkan kepada para responden sebagai variabel yang akan diteliti yaitu pegawai BAPPEDA Kota Bandung. sebagai berikut:

Penentuan jumlah sampel pada populasi adalah secara Stratifed random sampling methode,

Tabel 2. Sampel Penelitian

\begin{tabular}{|c|c|c|c|c|}
\hline \multirow{2}{*}{ Golongan } & \multicolumn{2}{|c|}{ Jumlah pegawai } & \multirow{2}{*}{ Total } & \multirow{2}{*}{$\begin{array}{c}\text { Persentase } \\
\text { Responden(\%) }\end{array}$} \\
\cline { 2 - 3 } & Laki-laki & Perempuan & & $6 \%$ \\
\hline II & 4 & - & 4 & $6 \%$ \\
\hline III & 33 & 20 & 53 & $79 \%$ \\
\hline IV & 8 & 2 & 10 & $15 \%$ \\
\hline Jumlah & 45 & 22 & 67 & $100 \%$ \\
\hline
\end{tabular}

Sumber: Hasil Pengolahan Data 2016

\section{Uji Hipotesis}

Untuk menguji koefisien jalur, terlebih dahulu harus menterjemahkan hipotesis penelitian ke dalam hipotesis statistik sebagai berikut :

Hipotesis : $\quad$ Menguji sub struktur 1, yaitu variabel kepemimpinan, value for money terhadap good government governance, sebagai berikut:

a. Rumus hipotesis operasional secara parsial $\left(\rho_{\mathrm{YX} 1}\right)$

$\begin{array}{lll}\mathrm{H}_{0} \quad: \rho_{\mathrm{YX} 1}=0 & \begin{array}{l}\text { Tidak terdapat pengaruh kepemimpinan terhadap good } \\ \text { government governance } \\ \text { Terdapat pengaruh kepemimpinan terhadap good } \\ \text { government governance }\end{array} \\ \mathrm{H}_{1} \quad: \rho_{\mathrm{YX} 1} \neq 0 & \end{array}$

Kriteria uji

Tolak $\mathrm{H}_{0}$ jika $\mathrm{t}_{\text {hitung }} \geq \mathrm{t}_{\text {tabel }}$

Terima $\mathrm{H}_{0}$ jika $\mathrm{t}_{\text {hitung }}<\mathrm{t}_{\text {tabel }}$

\section{b. Rumus hipotesis operasional secara parsial $\left(\rho_{\mathrm{YX} 2}\right)$}
$\mathrm{H}_{0} \quad: \rho_{\mathrm{YX} 2}=0$
Tidak terdapat pengaruh value for money terhadap good
$\mathrm{H}_{1}: \rho_{\mathrm{YX} 2} \neq 0 \quad \begin{aligned} & \text { Terdapat pengaruh value } \\ & \text { government governance }\end{aligned}$
government governance
government governance

Kriteria uji

Tolak $\mathrm{H}_{0}$ jika $\mathrm{t}_{\text {hitung }} \geq \mathrm{t}_{\text {tabel }}$

Terima $\mathrm{H}_{0}$ jika $\mathrm{t}_{\text {hitung }}<\mathrm{t}_{\text {tabel }}$ 
c. Rumus hipotesis operasional secara simultan $\left(\rho_{\mathrm{Y} 1 \mathrm{X} 1, \mathrm{X} 2}\right)$

$$
\begin{aligned}
& \mathrm{H}_{0}: \rho_{\mathrm{YX} 1, \mathrm{X} 2}=0 \\
& \mathrm{H}_{1}: \rho_{\mathrm{YX} 1, \mathrm{X} 2} \neq 0
\end{aligned}
$$

Kriteria uji

Tolak $\mathrm{H}_{0}$ jika $\mathrm{F}_{\text {hitung }} \geq \mathrm{F}_{\text {tabel }}$

Terima $\mathrm{H}_{0}$ jika $\mathrm{F}_{\text {hitung }}<\mathrm{F}_{\text {tabel }}$
Tidak terdapat pengaruh kepemimpinan dan value for money terhadap good government governance Terdapat pengaruh kepemimpinan dan value for money terhadap good government governance

Tabel 3. Hasil Uji Reliabilitas

\begin{tabular}{|l|l|c|c|c|}
\hline No. & \multicolumn{1}{|c|}{ Variabel } & Skor & R Kritis & Kategori \\
\hline 1. & Kepemimpinan $\left(\mathrm{X}_{1}\right)$ & 0,710 & 0,700 & Reliabel \\
\hline 2. & Value for Money $\left(\mathrm{X}_{2}\right)$ & 0,711 & 0,700 & Reliabel \\
\hline 3. & $\begin{array}{l}\text { Good Government } \\
\text { Governance }\left(\mathrm{X}_{3}\right)\end{array}$ & 0,706 & 0,700 & Reliabel \\
\hline
\end{tabular}

Hasil Uji Normalitas

Tabel 4. Uji Normalisasi Alat Ukur

One-Sample Kolmogorov-Smirnov Test

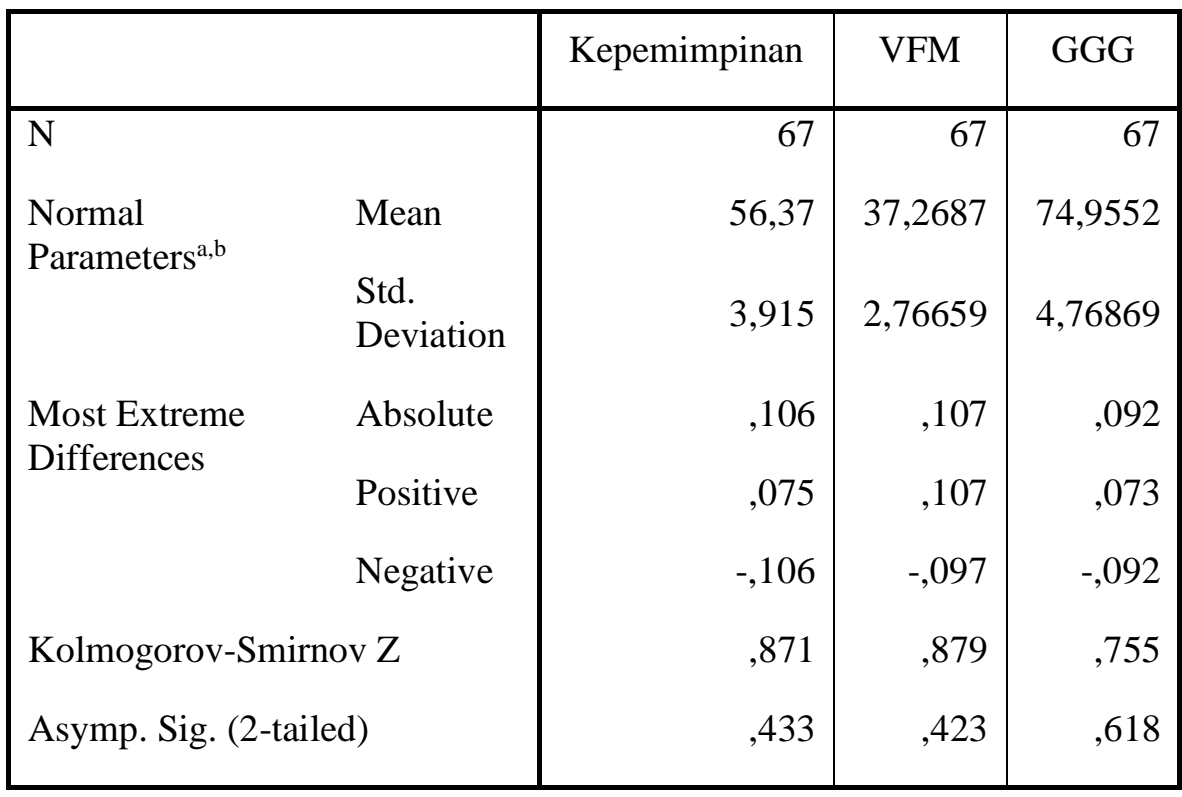

a. Test distribution is Normal.

b. Calculated from data.

$\mathrm{H}_{0}: p$-value $\leq 0,05 \quad$ Sampel tidak berasal dari populasi yang berdistribusi normal

$\mathrm{H}_{1}: p$-value $>0,05 \quad$ Sampel berasal dari populasi yang berdistribusi normal

Data pada tabel diatas. Menunjukan bahwa semua data variabel, yang terdiri dari variabel kepemimpinan, value for money, dan good government governance mengikuti sebaran data normal dengan menggunakan uji Kolmogorov-Smimov maupun Shapiro-Wilk dengan menunjukan nilai $p$ value $>0,05$, sehingga menerima $\mathrm{H}_{1}$ dan menolak $\mathrm{H}_{0}$ dengan demikian sampel berasal dari populasi berdistribusi normal. 


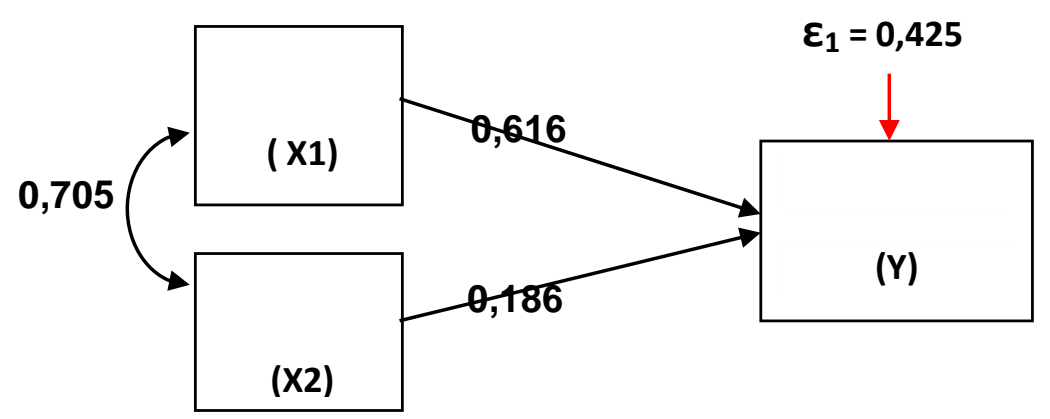

Gambar 1. Persamaan Jalur

Berdasarkan Gambar 1. maka diperoleh persamaan jalur sebagai berikut;

\begin{tabular}{|c|c|c|c|c|c|}
\hline \multicolumn{6}{|c|}{$\begin{array}{l}\text { Dimana: } \\
\mathrm{Y} \quad=\text { Good government governance } \\
\mathrm{X}_{1} \quad=\text { Kepemimpinan } \\
\mathrm{X}_{2}=\text { Value for money }\end{array}$} \\
\hline & \multirow{2}{*}{ Variabel } & \multirow{2}{*}{$\begin{array}{l}\text { Pengaruh } \\
\text { Langsung }\end{array}$} & \multicolumn{2}{|c|}{$\begin{array}{c}\text { Pengaruh Tidak } \\
\text { Langsung }\end{array}$} & \multirow{2}{*}{$\begin{array}{c}\text { Total } \\
\text { Pengaruh }\end{array}$} \\
\hline & & & $\overline{X_{1}}$ & $\overline{\mathbf{X}_{2}}$ & \\
\hline & Kepemimpinan & $37,95 \%$ & - & $8,08 \%$ & $46,02 \%$ \\
\hline & Value for Money & $3,46 \%$ & $8,08 \%$ & - & $11,54 \%$ \\
\hline & Total Pengaruh & Ke Y & & & $57,56 \%$ \\
\hline
\end{tabular}

Berdasarkan tabel di atas, terlihat bahwa variabel kepemimpinan $\left(\mathrm{X}_{1}\right)$ mempunyai pengaruh langsung sebesar $37,95 \%$ dan pengaruh tidak langsung melalui hubungannya dengan value for money $\left(\mathrm{X}_{2}\right)$ sebesar $8,08 \%$ sehingga total pengaruhnya sebesar $46,02 \%$

Variabel value for money $\left(\mathrm{X}_{2}\right)$ mempunyai pengaruh langsung sebesar $3,46 \%$ dan pengaruh tidak langsung melalui hubungannya dengan kepemimpinan $\left(X_{1}\right)$ sebesar $8,08 \%$, sehingga total pengaruhnya sebesar $11,54 \%$.

Hasil perhitungan koefisien determinasi $\left(R^{2}\right)$ yang dinyatakan dalam persentase mengambarkan besarnya kontribusi semua variabel bebas yaitu kepemimpinan $\left(\mathrm{X}_{1}\right)$ dan value for money $\left(\mathrm{X}_{2}\right)$ dalam menentukan variasi good government governance $(\mathrm{Y})$ adalah sebesar $\mathbf{5 7 , 5 6 \%}$.

\section{Uji Hipotesis}

Berdasarkan pengolahan data, kita melihat bahwa terdapat tiga substruktur sehingga pembahasan interpretasi hasil harus dilakukan bertahap berdasarkan substruktur tersebut. Berikut penjelasan dari masing-masing substruktur :

\section{a. Uji Parsial Variabel Kepemimpinan $\left(\mathrm{X}_{1}\right)$ Terhadap Good Government Governance $(\mathrm{Y})$}

Pengaruh parsial variabel kepemimpinan $\left(\mathrm{X}_{1}\right)$ terhadap good government governance $(\mathrm{Y})$ perlu dilakukan pengujian statistik, maka mengujinya menggunakan hipotesis statistik sebagai berikut

$$
\mathrm{H}_{0}: \rho_{Y X_{1}}=0
$$

Tidak terdapat pengaruh kepemimpinan terhadap good government governance. 
Terdapat pengaruh kepemimpinan terhadap good government governance.

Tabel 5. Pengujian Parsial Variabel Kepemimpinan $\left(X_{1}\right)$

Terhadap Good Government Governance (Y)

\begin{tabular}{|c|c|c|c|c|l|}
\hline Struktural & $\begin{array}{c}\text { Koefisien } \\
\text { jalur }\end{array}$ & $\mathbf{t}$-hitung & t- tabel & P-value & Kesimpulan \\
\hline$\rho_{Y} X_{1}$ & 0,747 & 9,051 & 1,99 & 0,000 & $\begin{array}{l}\mathrm{H}_{0} \text { di tolak terdapat } \\
\text { pengaruh yang } \\
\text { positif dan } \\
\text { signifikan antara } \\
\mathrm{X}_{1} \text { terhadap Y }\end{array}$ \\
\hline
\end{tabular}

Sumber : Data diolah 2016

Untuk koefisien jalur $X_{1}=0,747$, diperoleh nilai thitung sebesar 9,051 dengan mengambil taraf signifikansi $\alpha$ sebesar 5\%, maka nilai $\mathrm{t}_{\text {tabel }}=1,99$, sehingga dikarenakan $\mathrm{t}_{\text {hitung }}=9,051$ lebih besar dari $\mathrm{t}$ tabel $=1,99$, maka $\mathrm{H}_{0}$ ditolak atau dengan kata lain terdapat pengaruh yang signifikan antara kepemimpinan $\left(\mathrm{X}_{1}\right)$ terhadap good government governance $(\mathrm{Y})$.

b. Uji Parsial Variabel Value for Money $\left(\mathrm{X}_{2}\right)$ terhadap Good Government Governance (Y)

Pengaruh parsial variabel value for money $\left(\mathrm{X}_{2}\right)$ terhadap good government governance $(\mathrm{Y})$ perlu dilakukan pengujian statistik, maka mengujinya menggunakan hipotesis statistik sebagai berikut:

$$
\begin{array}{ll}
\mathrm{H}_{0}: \rho_{Y X_{2}}=0 & \begin{array}{l}
\text { Tidak terdapat pengaruh value for money terhadap good } \\
\text { government governance. }
\end{array} \\
\mathrm{H}_{1}: \rho_{Y X_{2}} \neq 0 & \begin{array}{l}
\text { Terdapat pengaruh value for money terhadap good } \\
\text { government governance }
\end{array}
\end{array}
$$

Tabel 6. Pengujian Parsial Variabel Value for Money $\left(\mathrm{X}_{2}\right)$ terhadap Good Government Governance (Y)

\begin{tabular}{|c|r|r|r|r|r|}
\hline $\begin{array}{c}\text { Strukt } \\
\text { ural }\end{array}$ & $\begin{array}{r}\text { Koef } \\
\text { isien jalur }\end{array}$ & $\begin{array}{r}\text { t }- \\
\text { hitung }\end{array}$ & $\begin{array}{c}\text { t- } \\
\text { tabel }\end{array}$ & $\begin{array}{c}\text { P- } \\
\text { value }\end{array}$ & Kesimpulan \\
\hline$\rho_{Y X_{2}}$ & 0,620 & 6,37 & 1, & 0, & $\begin{array}{l}\mathrm{H}_{0} \text { di tolak } \\
\text { terdapat } \\
\end{array}$ \\
& & 0 & 99 & 002 & $\begin{array}{l}\text { pengaruh yang positif } \\
\text { dan signifikan antara } \\
\mathrm{X}_{2} \text { terhadap Y Y }\end{array}$ \\
\hline
\end{tabular}

Sumber : Data diolah 2016

Untuk koefisien jalur $\mathrm{X}_{2}=0,620$, diperoleh nilai thitung sebesar 6,370 dengan mengambil taraf signifikansi $\alpha$ sebesar 5\%, maka nilai $\mathrm{t}_{\text {tabel }}=1,98$, sehingga dikarenakan $\mathrm{t}_{\text {hitung }}=6,370$ lebih besar dari $\mathrm{t}$ tabel $=1,98$, maka $\mathrm{H}_{0}$ ditolak atau dengan kata lain terdapat pengaruh yang signifikan antara value for money $\left(\mathrm{X}_{2}\right)$ terhadap good government governance $(\mathrm{Y})$.

\section{c. Uji Simultan Variabel Kepemimpinan $\left(\mathrm{X}_{1}\right)$ dan Value for Money $\left(\mathrm{X}_{2}\right)$, terhadap Variabel} Good Government Governance (Y)

Pengaruh secara simultan variabel kepemimpinan dan value for money terhadap good government governance menggunakan hipotesis statistik sebagai berikut:

$$
\mathrm{H}_{0}: \rho_{Y X_{1}}=\rho_{Y X_{2}}=0 \quad \text { Tidak terdapat pengaruh variabel }
$$




$$
\mathrm{H}_{1}: \rho_{Y X_{1}} \neq \rho_{Y X_{2}} \neq 0 \quad \text { Terdapat pengaruh variabel kepemimpinan }
$$

dan value for money terhadap good government governance.

Untuk menguji apakah terdapat pengaruh yang kuat secara simultan/bersamaan antara $\mathrm{X}_{1}$ (kepemimpinan) dan $\mathrm{X}_{2}$ (value for money) terhadap $\mathrm{Y}$ (good government governance), maka dapat dilihat dari hasil uji $\mathrm{F}$ sebagai berikut:

Tabel 7. Uji Simultan Variabel Kepemimpinan $\left(X_{1}\right)$ dan Value for Money $\left(X_{2}\right)$ terhadap Good Governance Govenance (Y)

ANOVA $^{\mathrm{a}}$

\begin{tabular}{|c|c|c|c|c|c|}
\hline Model & Sum of Squares & Df & Mean Square & $\mathrm{F}$ & Sig. \\
\hline 1 Regression & 862,805 & 2 & 431,402 & 43,271 &, $000^{\mathrm{b}}$ \\
\hline Residual & 638,061 & 64 & 9,970 & & \\
\hline Total & 1500,866 & 66 & & & \\
\hline
\end{tabular}

a. Dependent Variable: GGG

b. Predictors: (Constant), VFM, Kepemimpinan

Berdasarkan perhitungan diperoleh nilai $\mathrm{F}_{\text {hitung }}$ sebesar 43,271 dimana kriteria penolakan $\mathrm{H}_{0}$ jika $F_{\text {hitung }}$ lebih besar daripada $F_{\text {tabel }}$ atau $F_{0}>F_{\text {tabel }}$, dengan derajat bebas $V_{1}=2$ dan $V_{2}=67-3$ dan tingkat kepercayaan 95\%, maka dari tabel distribusi $\mathrm{F}$ didapat nilai $\mathrm{F}_{\text {tabel }}=3,14$. Karena 43,271 lebih besar dari 3,14, maka $\mathrm{H}_{0}$ ditolak, artinya bahwa terdapat hubungan secara linear antara $\mathrm{X}_{1}$ (kepemimpinan) dan $\mathrm{X}_{2}$ (value for money) terhadap $\mathrm{Y}$ (good government governance), atau terdapat pengaruh yang positif dan signifikan secara simultan (bersama-sama) $\mathrm{X}_{1}$ (kepemimpinan) dan $\mathrm{X}_{2}$ (value for money) terhadap Y (good government governance).

\section{Pembahasan}

\section{Pembahasan Hasil Analisis Deskriptif}

Berdasarkan hasil penelitian secara empiris, melalui wawancara dengan pihak-pihak terkait, melaui penyebaran kuisioner pada pegawai BAPPEDA yang menjadi responden dan hasil hasil analisis deskriptif dari jawaban responden, serta dengan melihat keterkaitan antara teori-teori yang berlaku dan fenomena-fenomena yang terjadi di lapangan, maka diperlukan pembahasan analisis deskriptif sebagai berikut:

\section{Pembahasan Hubungan Kepemimpinan dan Value for Money}

Berdasarkan hasil pengelolaan data, dapat disimpulkan bahwa hubungan antara variabel kepemimpinan $\left(\mathrm{X}_{1}\right)$ dengan value for money $\left(\mathrm{X}_{2}\right)$ mempunyai tingkat hubungan yang kuat dan searah karena nilainya positif dengan nilai $\mathrm{r}$ korelasinya yaitu 0,705 .

Pernyataan diatas dapat diartikan apabila kepemimpinan $\left(\mathrm{X}_{1}\right)$ naik sebesar satu satuan, maka diikuti dengan kenaikan besaran value for money $\left(\mathrm{X}_{2}\right)$ sebesar 0,705 satuan. Menurut Abdul Halim (2012:132) value for money merupakan konsep untuk mengukur ekonomi, efektivitas, dan efisiensi kinerja program, kegiatan dan organisasi. Konsep value for money adalah konsep yang penting dalam organisasi sektor publik sehingga seringkali disebut dengan inti dari pengukuran kinerja sektor publik. Kepemimpinan adalah inti dari pada manajemen membentuk organisasi yang baik. Efisiensi dan 
produktivitas yang tinggi dapat dicapai bila pemimpin berperan secara efektif dalam mengkoordinasikan semua bawahan di lingkunganya.

\section{Pembahasan Hasil Analisis Verifikatif}

Secara keseluruhan hasil hipotesis diatas telah memberikan hasil uji hipotesis yang dapat diterima, maka untuk memperkuat hasil penelitian tersebut dibahas kembali dan divalidasi dengan konsep dan teori. Hasil penelitian diatas menunjukan bahwa kepemimpinan, value for money berpengaruh signifikan terhadap good government governance.

\section{Pengaruh Kepemimpinan terhadap Good Government Governance secara parsial}

Berdasarkan pengolahan data, terlihat bahwa variabel kepemimpinan $\left(\mathrm{X}_{1}\right)$ mempunyai pengaruh langsung sebesar $37,95 \%$ dan pengaruh tidak langsung melalui hubungannya dengan value for money $\left(\mathrm{X}_{2}\right)$ sebesar $8,08 \%$, sehingga total pengaruhnya adalah sebesar $\mathbf{4 6 , 0 2 \%}$.

Kepemimpinan memiliki kontribusi yang paling dominan terhadap good government governance, semakin tinggi peran kepemimpinan maka akan meningkatkan good government governance. Pemimpin memiliki peranan penting dalam memajukan instansinya. Salah satu upaya pemimpin dalam memajukan instansi agar dapat menciptakan good government governance yaitu dengan pemimpin memberikan kesempatan kepada seluruh anggota dalam rangka meningkatkan kemampuannya baik melalui seminar, pelatihan dan lain-lain.

Untuk menciptakan pemerintah yang dapat mengelola pemerintah secara baik (good government governance), seorang kepala daerah/pemimpin perlu mempertimbangkan kesejahteraan pegawai. Hal ini sangat penting untuk organisasi pemerintahan yang baik hanya akan terbentuk jika dijalankan oleh orang-orang yang baik.

\section{Pengaruh Value for Money terhadap Good Government Governance secara parsial}

Berdasarkan pengolahan data, terlihat bahwa variabel value for money $\left(\mathrm{X}_{2}\right)$ mempunyai pengaruh langsung sebesar $3,46 \%$ dan pengaruh tidak langsung melalui hubungannya dengan kepemimpinan $\left(X_{1}\right)$ sebesar 8,08\%, sehingga total pengaruhnya sebesar 11,54\%.

Value for money mempunyai hubungan yang signifikan dengan good government governance. Semakin baik value for money suatu instansi, maka akan semakin baik pula good government governance. Value for money merupakan inti pengukuran kinerja pada organisasi pemerintah. Kinerja pemerintah tidak dapat dinilai dari sisi output yang dihasilkan saja, akan tetapi harus mempertimbangkan input, output, dan outcome secara bersama-sama. Bahkan, untuk beberapa hal perlu ditambahkan pengukuran distribusi dan cakupan layanan (equity \& service coverage). Permasalahan yang sering dihadapi oleh pemerintah dalam melakukan pengukuran kinerja adalah sulitnya mengukur output, karena output yang dihasilkan tidak selalu berupa output yang tidak berwujud, akan tetapi lebih banyak berupa intangible output. (Mardiasmo 2018:187)

Value for money terdapat pengaruh terhadap good government governance mempunyai hubungan yang erat. Permasalahan yang sering dihadapi oleh pemerintah dalam melakukan pengukuran kinerja adalah sulitnya mengukur output, karena output yang dihasilkan tidak selalu berupa output yang tidak berwujud, akan tetapi lebih banyak berupa intangible output. Pemerintahan yang bersih umumnya berlangsung di negara yang masyaraktnya menghormati hukum. Pemerintahan yang seperti ini juga disebut sebagai pemerintahan yang baik (good government governance). Untuk mewujudkan good governance diperlukan reformasi kelembagaan dan reformasi manajemen publik. Reformasi kelembagaan menyangkut pembenahan seluruh alat-alat pemerintah di daerah baik struktur maupun infrastrukturnya. Selain reformasi kelembagaan dan reformasi manajemen sektor publik, untuk mendukung terciptanya good governance, maka diperlukan serangkaian reformasi lanjutan terutama yang terkait dengan sistem pengelolaan keuangan pemerintah daerah. Tuntutan pembaharuan sistem keuangan tersebut adalah agar pengelolaan uang rakyat (public money) dilakukan secara transparan dengan mendasarkan konsep value for money sehingga tercipta akuntabilitas publik. 


\section{Pengaruh Kepemimpinan dan Value for Money terhadap Good Government Governance secara simultan}

Berdasarkan hasil pengolahan data, dapat disimpulkan bahwa total pengaruh variabel kepemimpinan $\left(\mathrm{X}_{1}\right)$ dan value for money $\left(\mathrm{X}_{2}\right)$ secara langsung dan tidak langsung terhadap good government governance $(\mathrm{Y})$ sebesar $57,5 \%$, dimana angka tersebut sama dengan hasil perhitungan koefisien determinasi $\left(\mathrm{R}^{2}\right)$. Dengan demikian dapat disimpulkan bahwa besarnya kontribusi variabel bebas yaitu kepemimpinan $\left(\mathrm{X}_{1}\right)$ dan value for money $\left(\mathrm{X}_{2}\right)$ dalam menentukan variasi good government governance (Y) adalah sebesar 57,5\%, sedangkan sisanya sebesar 42,5\% merupakan variabel lain yang mempengaruhi variabel good government governance yang tidak diteliti dalam penelitian ini.

Dalam mewujudkan good government governance diperlukan reformasi kelembagaan dan reformasi manajemen sektor publik yaitu reformasi sistem penganggaran, sistem akuntansi, sistem pemeriksaan, sistem manajemen keuangan daerah, dimana reformasi tersebut dilakukan secara transparan dengan mendasarkan konsep value for money (Mardiasmo, 2018:20). Berdasarkan teori tersebut dapat disimpulkan bahwa Tata kelola yang baik akan terwujud jika dalam pemerintahan akan dikelola oleh pemimpin yang bertanggungjawab dan melaksanakan tugasnya dengan efektif dan efisien. Untuk menciptakan pemerintah yang dapat mengelola pemerintah secara baik (good government governance), seorang kepala daerah/pemimpin perlu mempertimbangkan kesejahteraan pegawai. Hal ini sangat penting untuk organisasi pemerintahan yang baik hanya akan terbentuk jika dijalankan oleh orang-orang yang baik.

Berdasarkan hasil uji pengaruh kepemimpinan dan value for money terhadap good government governance secara simultan dengan menggunakan uji $\mathrm{F}$ atau ANOVA yang telah dihitung diperoleh nilai $F_{\text {hitung }}$ sebesar 43,271 dan nilai $F_{\text {tabel }}$ adalah sebesar 3,14 yang berarti $F_{\text {hitung }}>F_{\text {tabel }}$ dengan tingkat signifikansi 0,000. Maka dapat disimpulkan bahwa terdapat hubungan secara linear antara $\mathrm{X}_{1}$ (kepemimpinan) dan $\mathrm{X}_{2}$ (value for money) terhadap good government governance (Y). Hal tersebut menunjukkan bahwa semakin tinggi tingkat nilai kepemimpinan dan value for money maka semakin tinggi tingkat pencapaian good government governance pada BAPPEDA Kota Bandung.

\section{KESIMPULAN DAN SARAN}

\section{A. Kesimpulan}

Berdasarkan hasil analisis gambaran kepemimpinan di BAPPEDA Kota Bandung berada pada kategori baik, namun masih terdapat aspek yang lemah yaitu kemampuan pemimpin dalam mengatur sumber daya organisasi secara efektif dan efisien. Gambaran Value for money di BAPPEDA Kota Bandung berada pada kategori yang baik, namun masih terdapat aspek lemah yaitu melakukan pembelanjaan dengan tingkat kualitas tertentu pada harga terbaik dan nilai rata-rata terendah kedua yaitu pada pernyataan pembuatan RAPB telah disesuaikan dan disetujui oleh pemimpin perlu dilaksanakan sesuai dengan aturan. Sedangkan untuk gambaran good government governance di BAPPEDA Kota Bandung berada pada kategori yang baik, namun masih ada aspek yang rendah yaitu menghubungkan antara pencapaian kinerja suatu program/ kegiatan dengan tujuan strategis visi misi. Selain itu, aspek terendah kedua yaitu pada pernyataan Belanja yang dilakukan sesuai dengan kebutuhan daerah.

Hubungan kepemimpinan dan value for money di BAPPEDA Kota Bandung mempunyai hubungan yang sangat kuat dan searah karena nilainya positif. Artinya bahwa jika kepemimpinan naik sebesar satu satuan maka diikuti dengan kenaikan besaran value for money sebesar 0,705 satuan.

Terdapat pengaruh yang positif dan signifikan baik secara parsial maupun simultan baik secara langsung maupun tidak langsung dari variabel kepemimpinan dan value for money terhadap good government governance di BAPPEDA Kota Bandung, dimana variabel yang paling dominan pengaruhnya adalah variabel Kepemimpinan $\left(\mathrm{X}_{1}\right)$. Artinya bahwa semakin tinggi tingkat nilai kepemimpinan dan value for money maka semakin tinggi tingkat pencapaian good government governance pada BAPPEDA Kota Bandung. 


\section{B. Saran-saran}

\section{Saran Akademis}

Dalam rangka meningkatkan pengembangan keilmuan dan manfaat bagi penelitian, maka penelti memberikan beberapa saran sebagai berikut:

1. Hasil penelitian ini diharapkan dapat dijadikan sebagai salah satu referensi dan sumber informasi bagi para peneliti lain yang akan melakukan penelitian sejenis atau penelitian lanjut yang terkait dengan penelitian ini.

2. Perlu dilakukan kajian penelitian dengan ruang lingkup yang lebih mendalam dengan penambahan beberapa variabel independen dan variabel dependen lainnya termasuk dengan menambahkan beberapa dimensi dan indikatornya.

3. Dalam penelitian lanjut perlu dipertimbangkan dengan menggunakan objek penelitian yang lebih luas dan jumlah sampel yang lebih banyak dengan menggunakan alat analisis yang berbeda.

\section{Saran Praktis}

1. Dalam rangka meningkatkan kepemimpinan, value for money dan good government governance di BAPPEDA Kota Bandung.

a. Dalam rangka meningkatkan kepemimpinan di BAPPEDA Kota Bandung perlu adanya peningkatan kemampuan pemimpin dalam mengatur sumber daya organisasi secara efektif dan efisien.

b. Dalam upaya meningkatkan value for money, perlu adanya upaya dari pemimpin untuk mendukung dilakukannya pengelolaan dana publik yang mendasar pada konsep value for money, maka memerlukan sistem pengelolaan keuangan daerah dan anggaran daerah yang baik dengan ekonomi, efisiensi, dan efektif.

c. Dalam rangka peningkatan good government governance pada Badan Perencanaan Pembangunan Daerah (BAPPEDA) Kota Bandung, maka langkah awal yang perlu dilakukan adalah perlu program kerja harus disesuaikan dengan tujuan strategis visi misi. Tata kelola yang baik akan terwujud jika dalam pemerintahan akan dikelola oleh pemimpin yang bertanggungjawab dan melaksanakan tugasnya dengan efektif dan efisien.

\section{DAFTAR PUSTAKA}

\section{Kelompok Buku}

A, Affandi. 2012. Peran Knowledge Management dalam Menciptakan Keunggulan Bersaing Berkelanjutan Pada Intsansi Pendidikan tinggi Ilmiah. Bandung:UNPAS

Abdul, Halim. 2012. Akuntansi Sektor Publik. Jakarta: Salemba Empat

Ancok, Djamaludin,2010. Tehnik Skala Penyusunan Pengukur. Pusat penelitian kependudukan. UGM :Yogyakarta

Harun, Al-Rasyid. 2008. Teknik Penarikan Sampel dan Penyusunan Skala. Bandung: Universitas Padjadjaran

Indra, Bastian. 2010. Akuntansi Sektor Publik Suatu Pengantar Edisi Ketiga. Penerbit Erlangga :Jakarta Imam, Ghozali. 2011. Aplikasi Analisis Multivariate denan program IBM SPSS 19. Semarng: Universitas Diponogoro

Indriantoro. 2011. Metodologi Penelitian Bisnis. Yogyakarta: Penerbit DPFE

Indrawan, Rully dan Poppy Yaniawati. 2014. Metodologi Penelitian Kuantitatif, Kualitatif, dan Campuran untuk Manajemen, Pembangunan, dan Pendidikan. Bandung: PT Refika Aditama.

Irawan. 2010. Metode Peneltian Sosial: Suatu Teknik Penelitian Bidang Kesejahteraan Sosial dan Ilmu Sosial Lainnya. Bandung: Remaja Rosdakarya

J. Supranto. 2008. Statistik Teori \& Aplikasi, Cetakan Kedua. Jakarta: Erlangga

Kaloh. 2010. Kepemimpinan Daerah. Jakarta: Sinar Grafika

Keating, J, Charles. 2015. Kepemimpinan : Teori dan Pengembangannya. Kanisius: Yogyakarta 
Kusnendi dan Hendar. 2010. Ekonomi Koprasi. Jakarta: Lembaga Penerbit Ekonomi UI

Mardiasmo. 2018. Akuntansi Sektor Publik. Yogyakarta: CV. Andi

------. 2007. Akuntansi Sektor Publik. Yogyakarta: CV. Andi

Mohamad, Mahsun. 2013. Pengukuran Kinerja Sektor Publik.BPFE. Yogyakarta.

Mulyasa.2013. Manajemen \& Kepemimpinan Kepala Sekolah. Bandung: PT. Remaja Rosdakarya

Mulyadi. 2016. Akuntansi Manajemen: Akuntansi Manajemen Konsep, Manfaat, dan Rekayasa. Edisi 3. Jakarta: Salemba Empat.

Nawawi, Hadari. 2009. Kepemimpinan Mengefektifkan Organisasi. Yogyakarta : Gajah Mada Univercity Press

Nazir. 2010. Metodologi Penelitian. Jakarta: Ghalia Indonesia

Paslong, Harbani. 2015. Kepemimpinan Birokrasi. Makassar: Alfabeta

Rivai, Veithzal, dkk . 2016. Kepemimpinan dan Perilaku Organisasi. Cetakan kedua. Jakarta: PT. Raja Grafindo

---------. 2004. Manajemen Sumber Daya Manusia Untuk Perusahaan. Cetakan Pertama. Jakarta: PT. Raja Grafindo

Sekaran. 2013. Research Methods For Business : A Skill Building Aproach, 3rd edition. New York : John Wiley and Sons, Inc

Sedarmayanti. 2012. Good Governance Kepemerintahan Yang Baik. Bagian Kedua Edisi Revisi. Bandung: CV. Mandar Maju

Sinambela, Lijan Poltak. 2011. Reformasi Pelayanan Publik. Jakarta: Sinar Grafika Omset

Sitepu. 2005. Analisis Jalur (Path Analysis) unit pelayanan Statistika Jurusan Statistika. Bandung:FMP IPA UNPAD

Sudjana. 2009. Metode Statistika. Bandung: Tarsito

Sugiyono. 2015. Metode Penelitian Pendidikan (Pendekatan Kuantitatif, Kualitatif, dan R\&D). Bandung : Alfabeta.

---------. 2013. Metode Penelitian Pendidikan (Pendekatan Kuantitatif, Kualitatif, dan R\&D). Bandung: Alfabeta.

-------. 2010. Metode Penelitian Kuantitatif, Kualitatif, dan R\&D. Bandung : Alfabeta.

-------.2010. Metode Penelitian Kuantitatif dan Kualitatif. Bandung:Penerbit Alfabeta

-------2011. Metode Penelitian Kuantitatif, Kualitatif dan $R$ \& D. Bandung:Penerbit Alfabeta

--------. 2000. Statistika untuk Penelitian. Cetakan Ketiga. Bandung: Alfabeta

-------. 2010. Metodelogi Penelitian Administrasi. Bandung: Alfabeta

Sutisna, Oteng. 2006. Studi Pengembangan Pendidikan Dasar Teoritis untuk Praktek Profesional. Bandung: Angkasa

Siagan, S.P. 2010. Manajemen Sumber Daya Manusia. Jakarta: Bumi Aksara

Tjiptono, Fandy dan Anastasia Diana. 2006. Kepemimpinan dan Perilaku Organisasi. Jakarta: PT. Rajagrafindo Pesada

Undang-Undang

Undang-undang Nomor 28 Tahun 1999. Penyelenggaraan Negara yang Bersih dan Bebas Korupsi, Kolusi, dan Nepotisme

Undang-undang Nomor 108 Tahun 2000. Pertanggungjawaban Kepala Daerah

Kelompok Penelitian

Endang Kuswoyo.2014.Analisis Value for Money dalam Meningkatkan Mutu Pelayanan Publik pada Koni Provinsi Bengkulu (Studi Kasus pada Program Upaya Pembinaan Atlet)

Gustati \& Ferdawati. 2009. Sinergitas Good Governance, Demokrasi, dan Reinventing Government dalam Mensejahterakan Masyarakat

Miswaty. 2013. Analisis Pengaruh Penerapan Good Governance dan pengendalilan Internal Organisasi terhadap Kinerja Pegawai pada Pemerintahan Kota Balikpapan

Nurfaisal.2003. Hubungan Antara Gaya Kepemimpinan Kepala Sekolah Dan Kepuasan Kerja Dengan Displin Kerja Guru.

Rosalinda Cahya Hutahuruk. 2009. Pengaruh Kepemimpinan terhadap Kinerja Pegawai

Stephan Gerhard Huber (2004). School Leadership and Leadership Development

Tri Siwi Nugrahani. 2007. Analisis Penerapan Konsep Value For Money pada Pemerintahan Daerah Istimewa Yogyakarta 